\title{
China and the Mekong Region
}

\section{Tim Summers}

\section{(2) OpenEdition}

\section{Journals}

Electronic version

URL: http://journals.openedition.org/chinaperspectives/4083

ISSN: 1996-4617

Publisher

Centre d'étude français sur la Chine contemporaine

Printed version

Date of publication: 1 July 2008

Number of pages: 68-77

ISSN: 2070-3449

\section{Electronic reference}

Tim Summers, "China and the Mekong Region », China Perspectives [Online], 2008/3 | 2008, Online since 01 July 2011, connection on 28 October 2019. URL : http://journals.openedition.org/ chinaperspectives/4083

(C) All rights reserved 
C

\section{China and}

\section{the Mekong Region}

TIM SUMMERS

This paper looks at constructions of the Mekong region with a particular focus on Chinese views. It draws out the differences between central and provincial Chinese perspectives, shows Chinese privileging of Greater Mekong Subregion economic cooperation in constructing the region, and outlines tensions between Chinese participation in and differentiation from the region.

\section{Introduction ${ }^{(1)}$}

1 his paper looks across China's southwest continental borders to examine China in relation to the Mekong region. As a preliminary enquiry into constructions of the region by different parties in accordance with their interests and ideological dispositions, this paper focuses on Chinese constructions. It seeks to identify the motivations behind China's engagement with the region, and under what conditions China is construed as part of or separate from the Mekong region. It further examines the different conceptions of the region by Chinese authorities at the central and provincial level. ${ }^{(2)}$ The research is set against a background of diverse and increasing Chinese engagement with southeast Asia, ${ }^{(3)}$ and the broader phenomena of globalisation and regionalisation, which have engendered growth in transborder institutions and in mechanisms for regional cooperation and integration.

The concept of region ${ }^{(4)}$ is a contested one, and any attempt to start with a definition of region, the related concepts of regionalisation or regionalism, or specifically of the "Mekong region" inevitably privileges a particular understanding. This paper does not, for example, look only at what has become known as the Greater Mekong Subregion (see below). Instead it takes a constructivist approach to regional formation, which views regions as politically, socially, historically, and ideologically constructed, not simply as given geographical areas. This is not to argue that regional constructions are somehow purely abstract or arbitrary and without any "objective" reality; rather, these constructions are informed by a range of contingent geographical, historical, political, economic, and social factors. ${ }^{(5)}$ I argue below that this approach to regional formation is borne out by the literature, which offers a range of different constructions of the "Mekong region" based either on the Mekong river basin, a political geography defined by functional perspectives of security or economic development, or through the region's relationship with larger regional structures such as the Association of Southeast Asian Nations (ASEAN). Some of these constructions include China or parts of it, and others place the region outside China's borders. It is this issue, of what happens at the intersection or overlap of these various regional constructions, that not only raises the question of whether China is construed as part of or separate from the region, but also underlies the differences that exist between central and provincial Chinese approaches. ${ }^{(6)}$

The paper begins by introducing the two key Mekong region institutions and the types of connections in the region, then

1. I am grateful to my supervisor at The Chinese University of Hong Kong, Professor Arif Dirlik, for his guidance and for his comments on an earlier draft of this paper, and to the anonymous reviewer(s) for their comments.

2. For a provincial perspective on international relations see for example P. Cheung and J. Tang, "The External Relations of China's Provinces," in David Lampton (ed), The Making of Chinese Foreign and Security Policy in the Era of Reform, 1978-2000, Stanford, Stanford University Press, 2001.

3. See for example, Susan Shirk, China: Fragile Superpower, New York, Oxford University Press, 2007, pp. $111 \mathrm{ff}$

4. For the purposes of this paper, "region" is used in a supra- or trans-national sense, and not for the development of subnational regions within nation states.

5. See for example Arif Dirlik, "The Asia-Pacific Idea: Reality and Representation in the Invention of a Regional Structure," in What Is In A Rim? second edition, Lanham, MD, Rowman and Littlefield, 1998. Following Dirlik (op. cit., p. 33, note 2) I will use "region" as a general term when setting out constructs of human activity or analyses of the different understandings of the "Mekong region" in the existing literature, and use "area" when referring to the physical geographical entity.

6. There is another layer of analysis, which would look at the involvement of the "southwest region" within China. 
A tributary of the Mekong River, Xishuangbanna, Yunnan Province (C) Tim Summers problematises different constructions of the region. This is followed by discussion of China's role in and views on the region and these institutions, differentiated at the central and provincial levels. Finally, the paper shows that economic motivations dominate Chinese constructions of the region, and outlines the tension between China's participation in and differentiation from the region.

\section{Institutional arrangements in the Mekong region}

A number of institutional arrangements (over)determine the Mekong region, which takes its name from the river that flows $4,800 \mathrm{~km}^{(7)}$ from the Tibetan plateau through Yunnan Province, Laos, Myanmar, and Thailand, then on through Cambodia and into a delta in the south of Vietnam. ${ }^{(8)} \mathrm{I}$ focus below on the two institutions that relate most directly to the Mekong. These are the Greater Mekong Subregion (GMS) Programme for Economic Cooperation, of which China is a key member, and the Mekong River Commission (MRC), of which China is not a member but whose work is affected directly by China's actions in the upstream Mekong river. Wider developments in East Asia and in particular between China and Southeast Asia, including through ASEAN, on which there is a burgeoning literature, are also relevant, although they cover a much wider range of issues than the scope of this paper.

The history of conceptualisations of the Mekong region is an important background to contemporary constructions of the region. Sachchidanand Sahai has traced this history leading to the nineteenth century French expeditions that used the Mekong to "open up" China for mineral exploration and trade, and their subsequent realisation of the difficulties in developing a navigable route along the Mekong to Yunnan Province, ${ }^{(9)}$ an approach that implicitly places China outside the Mekong region as the target of trade to be reached by passing through the region.

\section{The Mekong River Commission (MRC) ${ }^{(10)}$}

This paper's focus on contemporary institutional structures begins with the establishment of the Mekong Committee, sponsored in 1957 by the United Nations to coordinate water resource development among the downstream nations of Cambodia, Laos, Thailand, and South Vietnam. After what Jacobs describes as an early period of "optimism" and substantial funding identified for regional projects, conflict in the peninsula interrupted the Committee's work from the

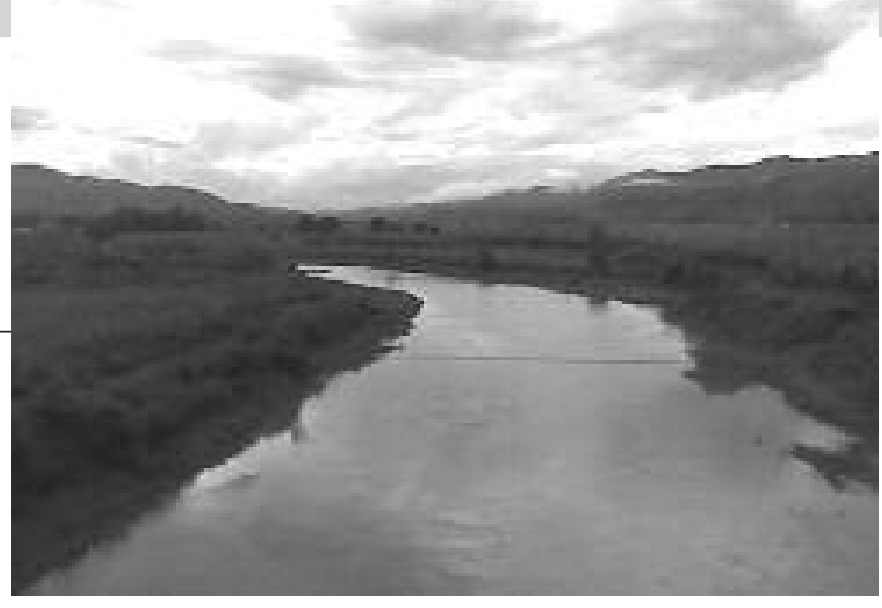

1970s. Laos, Thailand, and Vietnam (re)formed an Interim Mekong Committee in 1978. Subsequently Cambodia joined the new Mekong River Commission (MRC) at its formation in 1995. The MRC's stated aim is sustainable development of the Mekong River Basin, an area that is substantially more important to downstream than to upstream states, as the basin spreads out to cover nearly all of Cambodia, much of Laos, and the fertile and productive delta in Vietnam. It operates through a series of programmes agreed between the member states and supported by a secretariat.

The MRC's current membership of Cambodia, Laos, Thailand, and Vietnam reflects its historical origins. Jacobs says that the "[original] organization was limited to membership of the lower Mekong nations only, as China was not a member of the United Nations in the early 1950s and Burma was simply not interested in participating." Although the 1995 Legal Agreement allows for China's membership, China has, according to Jacobs, not expressed an interest in joining the (post-1995) MRC, (II) though both China and Myanmar have since become MRC "Dialogue Partners." Jacobs' 1995 article paints a generally positive view of the potential for MRC collaboration with China. He does not, for example, discuss the Manwan dam, completed by China on the upper river in 1995 and later a source of contention. His 2002 article, however, identifies China's role as a key challenge for the MRC, which by then had shifted its focus to monitoring and macro-management of the river basin

7. Jeffrey Jacobs, "Mekong Committee History and Lessons for River Basin Development," Geographical Journal, 161/2, 1995, cites Mekong River Secretariat 1989 figures of around $4,200 \mathrm{~km}$ for the length of the river (p. 354). Chinese sources put the length at over $4,800 \mathrm{~km}$, and this is the figure currently used on the Mekong River Commission Secretariat website (www.mrcmekong.org). As I comment towards the end of the paper, naming of the river varies along its length. It is worth noting that much of the literature on MRC makes little reference to the GMS

8. See Evelyn Goh, Developing the Mekong: Regionalism and Regional Security in ChinaSoutheast Asian Relations, London, International Institute for Strategic Studies, Routledge, 2007, p. 27, for a summary of the plethora of institutional arrangements in the wider Mekong region.

9. Sachchidanand Sahai, The Mekong River: Space And Social Theory, Delhi, B.R. Pub. Corp., 2005. See also Milton 0sborne, The Mekong: Turbulent Past, Uncertain Future, St Leonards, NSW, Allen and Unwin, 2000, for more on the French expeditions.

10. This summary is drawn from Jacobs art. cit., Jacobs, "The Mekong River Commission: Transboundary Water Resources Planning and Regional Security," Geographical Journal, 168/4, 2002, pp. 360-63, and the MRC website, www.mrcmekong.org.

11. Jacobs art.cit., 2002, p. 356 (citing Mekong Secretariat, The Mekong Committee: $A$ Historical Account, Bangkok 1989) and p. 361. Goh says that China "refuses to become a member of the institution" (op. cit., p. 38). 
rather than specific projects or dam construction. This is in contrast to the more economic or integrationist agenda of the Greater Mekong Subregion (GMS), to which I now turn. ${ }^{(12)}$

\section{The Greater Mekong Subregion (GMS)}

The GMS programme was established in 1992 following agreement by Cambodia, China, Laos, Burma, Thailand, Vietnam (henceforth the "GMS members"), and the Asian Development Bank (ADB). ${ }^{(1)}$ The geographical area covered (the "GMS area") includes the countries of Cambodia, Laos, Myanmar, Thailand, and Vietnam, with the addition of China's Yunnan Province and, from 2005, China's province-level Guangxi Zhuang Autonomous Region (see below for more on China's membership). ${ }^{(14)}$ By 2007 the population of this area had reached 320 million. ${ }^{(15)}$

The ADB stresses the economic nature of GMS cooperation, described in its early days as a loose mechanism for cooperation in a "natural economic area," ${ }^{(6)}$ with priority given to transport links and energy infrastructure rather than to the creation of a more formal structure such as a trade bloc. The momentum of GMS cooperation was interrupted after 1997 by the Asian financial crisis, but a new phase began around 2001, ${ }^{(17)}$ marked by agreement among GMS heads of government on a Strategic Framework for 2002 to 2012 at their first GMS summit in 2002. This "envisioned "a GMS that is more integrated, prosperous, and equitable." (18) There has also been a steady broadening over time of the scope of the GMS programme, with the inclusion of cooperation to manage challenges such as narcotics and human trafficking, environmental degradation, and the spread of infectious diseases such as avian flu and HIV/AIDS. ${ }^{(19)}$ In this context, there is brief acknowledgement by the ADB that the transport links that formed the core of much of the regional integration have also led to an increase in the transborder nature of such challenges, and not just to facilitated trade relations or the promotion of economic development. ${ }^{(20)}$ It operates its series of programmes through consultation and coordination between the member states, with an active Secretariat role played by the ADB.

\section{Problematising the Mekong region}

Before turning to China and the region, it is important to look for context in the ways that the literature constructs or problematises the region. I suggest this is done through four different themes: economic cooperation and development, river and basin management, security, and wider integration. Most of the literature that construes the region as GMS focuses on economic development and cooperation, examining issues such as whether the GMS has delivered economic development, and the different levels of development within the region; ${ }^{(21)}$ on whether the GMS, which in one account does "not aim at economic integration of the participating countries," (22) is likely to be engulfed by ASEANbased free-trade arrangements; or on examining the potential for bilateral economic cooperation. ${ }^{(23)}$

12. The ADB representative at the fifth GMS conference in November 1995 said that the MRC, newly (re)formed that year, had an important role to play in promoting subregional economic cooperation (ADB 1996, Economic cooperation in the GMS: Facing the challenges, Manila, Asian Development Bank, 1996, p. 19), but the MRC representative a the same conference made clear that he saw the MRC's goal as "sustainable development of the Mekong river basin" (ibid., p. 69).

13. This account of the development of GMS cooperation is based largely on ADB policy statements, studies, public records of meetings, technical assistance documents for specific projects, public relations material or brochures, and the ADB website (www.adb.org/GMS). Its own characterisation of its role shifts over time, but consistently sets out to avoid any impression that it might be the lead organisation in GMS development. As the Secretariat to the GMS, the ADB has been responsible for drawing up proposals and planning activity. Combined with its role as financial coordinator and provide this gives it a strong influence over the developments within the GMS. There is also opposition to the ADB's role and strategy, including from NGOs such as Oxfam. Philip Hirsch analyses some of the regional resistance to ADB activity in "Globalisation, Regionalisation and Local Voices: the Asian Development Bank and rescaled politics of environment in the Mekong Region," Singapore Journal of Tropical Geography, 22/3, 2001, pp. 237-251.

14. The use of the term "subregion" rather than "region" apparently stems from ADB division of its business in Asia into the large regions of East Asia, Southwest Asia, etc. As the six countries along the Mekong cover parts of both the East Asia region (China) and Southwest Asia (the other five countries), "subregion" therefore fits with the ADB's existing regional structure. This creates a subregional level "lower" than the existing regions defined by $A D B$ but crossing from one region to another (personal information, July 2008). The ADB's role and agenda lie outside the scope of this paper but deserve separate detailed analysis.

15. ADB, Strategic Framework 2002-2012: Mid-Term Review, 2007, downloaded from www.adb.org July 2008

16. ADB, Economic Cooperation in ihe GMS: Facing the Challenges, Manila, Asian Development Bank, 1996, p. 3

17. Medhi Krongkaew, "The development of the Greater Mekong Subregion: Real promise or fake hope?" Journal of Asian Economics, 15/5, 2004 pp. 977-998.

18. Cited in ADB, Mid-Term Review, p. 5.

19. See for example ADB, Technical Assistance to the Kingdom of Cambodia, Lao PDR, and Socialist Republic of Vietnam For Preparing the GMS Regional Communicable Diseases Control Project, Manila, Asian Development Bank, 2004.

20. ADB, The GMS, Beyond Borders: Regional Cooperation Strategy and Program 2004 2008, Manila, Asian Development Bank, 2004, pp. 48-49.

21. Krongkaew, art. cit., also claims a strong "pivotal" role for Thailand, which enjoys the highest per capita income levels and tends to dominate the terms of trade.

22. Mya Than, "Economic Cooperation in the Greater Mekong Subregion," Asian-Pacific Economic Literature, 11/2, 1997, p. 41.

23. Siriluk Masviriyakul, "Sino-Thai Strategic Economic Development in the Greater Mekong Subregion (1992-2003)," Contemporary Southeast Asia, 26/2, 2004, pp. 302-319, sees great potential for further trade between Yunnan and northern Thailand, but also highlights transborder problems. Yang Hongchang, Yunnan sheng yu Meigong he quyu hezuo: Zhongguo difang zizhuquan de fazhan, Hong Kong, Chinese University Press 2001, focuses on Yunnan and its trade with neighbours, but also integrates (traditional and non-traditional) security issues into his analysis. Note that Yang talks about the Mekong "region" rather than "subregion." 
A second way of problematising the region, for example in writings on the MRC, conceives the river and basin as the key determinants of the region's identity, often with a strong emphasis on hydropower development and hence a focus on relations between upstream and downstream countries. As shown in a detailed and specialist account by Hiroshi Hori, ${ }^{(24)}$ a Japanese engineer with decades of personal experience working on projects along the Mekong, it is not only Chinese dam building that serves as a potential source of conflict, ${ }^{(25)}$ but also, for example, Vietnamese opposition to Thai dam building. Hori also criticises a 1962 report commissioned by the Mekong Committee for viewing "the Lower Mekong Basin as a single enclosed "system." (26) Separately, Darrin Magee argues that Yunnan's participation in China's Western Development Strategy legitimises the development of hydropower to supply eastern markets within China, while its membership in the GMS similarly legitimises hydropower development to meet increased power demand in the Mekong region (understood here as the GMS area, showing the increased dominance of the GMS conception). ${ }^{(27)}$ Karen Bakker uses discourse analysis to show how much of the development discourse is based on an assumption that the "undeveloped" river is uncommodified, and hence the discourse is underpinned by a rescaling from the local to the urban, regional, or international level, with hydrodevelopment "portrayed as the creation of uses and users, rather than the reprioritisation or even displacement of uses." (28)

A third understanding of the region and its institutions is in terms of regional security. This approach broadens out the issues to include ASEAN, and hence puts less emphasis on either the GMS or MRC. Evelyn Goh takes the Mekong basin - a "natural ecological unit" with a "common development imperative" - as a case study of the potential domination by China of "the part of the region that has already been 'ceded' to the Chinese sphere of influence." ${ }^{(29)}$ Jörn Dosch acknowledges the economic focus of the GMS mechanism, but claims that "security has been an equally if not more important dimension," ${ }^{(30)}$ with the building of trust and confidence as its main achievement, although the ADB's "necessary" role in this, along with what Dosch highlights as the elite nature of the process, should raise questions about the sustainability of such gains.

Fourthly, an emphasis on regional integration is found particularly in ADB publications. "The GMS - Beyond Borders: Regional Cooperation Strategy and Program 2004-2008" reflects a stronger integrationist agenda, including a claim that the GMS is "no longer a simple group of countries: it is a regional entity." ${ }^{(31)}$ This agenda is less apparent in the ADB's 2007-09 Programme Update, although it still talks about the "GMS vision of a prosperous, integrated and harmonious subregion." (32)

Drawing together elements from these different conceptualisations, Xiangming Chen examines the GMS as part of a wider study of the evolution of borders and transnational spaces in Asia. ${ }^{(3)} \mathrm{He}$ suggests that the Mekong River "bind[s] the riparian GMS countries together" and that "the 1990s marked a new decade for the Mekong River region with the launch of the GMS programme and the opening of China's southwest." ${ }^{\left({ }^{4}\right)}$ But by privileging the GMS in his analysis, he ends up describing the MRC as a "mechanism for GMS cooperation," ${ }^{(35)}$ even though (as he notes) not all GMS members belong to the MRC, and their remits differ. Bringing in non-state actors, Chen identifies three main drivers of integration and cooperation: decentralisation, which has led to increased border trade without the need for government projects; ethnic ties; ${ }^{(36)}$ and the transport links at the heart of inter-state cooperation facilitated by the ADB.

This analysis shows the different conceptions of the region that can arise in line with the constructivist approach outlined above. The questions then become how different conceptions of the region occur, where their boundaries lie, who

24. Hiroshi Hori, The Mekong: Environment and Development, Tokyo, United Nations University Press, 2000.

25. As for example in Goh, op. cit., and Fred Pearce, When the Rivers Run Dry: Water, the Defining Crisis of the Twenty-first Century, Boston, Beacon Press, 2006.

26. Hori, op. cit., p. 129. For example, the report failed to anticipate the impact on the basin of later mass migration from the lower basin to cities outside it such as Bangkok.

27. Darrin Magee, "Powershed Politics: Yunnan Hydropower Under Great Western Development," The China Quarterly, 185, 2006, pp. 23-41.

28. K Bakker, "The Politics of Hydropower: Developing the Mekong," Political Geography, 18, 1999 , p. 220, italics in original.

29. Goh, op. cit., p. 9, though it is not clear whose perception this is.

30. Jörn Dosch, "Crossing Cold War Divides: Cooperation in the Mekong Valley," in The Changing Dynamics of Southeast Asian Politics, Boulder, Lynne Rienner Publishers, 2007, pp. 117 ff.

31. ADB, The GMS, Beyond Borders: Regional cooperation strategy and program 20042008, Manila, Asian Development Bank, 2004, p. 25.

32. ADB, Regional Cooperation Strategy and Program Update, The Greater Mekong Subregion - Beyond Borders (2007-2009), Manila, Asian Development Bank, 2006, p. 1, my italics.

33. Chen Xiangming, As Borders Bend: Transnational Spaces on the Pacific Rim, Rowman \& Littlefield, 2005

34. Ibid., p. 204

35. Ibid., p. 195

36. These ethnic ties merit further study. Don McCaskill, Prasit Leepreecha, and He Shaoying (eds), Living in a Globalized World: Ethnic Minorities in the Greater Mekong Subregion, Chiang Mai, Thailand, Mekong Press, 2008, aims to look at the impact of globalisation, regionalism and nationalism on the cultures, social systems, and environments of the ethnic minorities in the GMS region. 
acts as the agent of these constructions, the region's "purpose," and if and how these are further broken down into (sub)regions or are themselves seen as subsets of larger regional structures. I suggest that the multiplicity of institutional structures in the Mekong region, with their different members and objectives, is an empirical manifestation of these varied constructions of the region. Dosch's passing comment that the GMS "look[s] more like a collection of many subregions, instead of one cohesive subregion" (37) highlights the lack of "intrinsic" regional coherence against efforts to present the region as "naturally" occurring or constituted. It is for this reason that we cannot examine China and the Mekong by privileging any one of the institutions that cover the area under study.

\section{The role of China in the Mekong region}

Having looked at the two main regional institutions and the problematisation of the region, I now turn to Chinese perceptions of the region, breaking these down into the central and provincial levels of the government system, and using material from China-based academics. ${ }^{(38)}$ As noted above, it is important to bear in mind that China's relationship with the Mekong should not be reduced to its activities in the GMS, but given China's membership of this organisation, it nonetheless features strongly in this section.

It is worth first highlighting the peculiar fact that China's geographical participation in the GMS (the "GMS area") is limited to only part of the country, initially Yunnan, with Guangxi joining in 2005. The reasons for this are not much explored in the literature. Yang suggests that China's size meant it was not "appropriate" for the whole country to par-

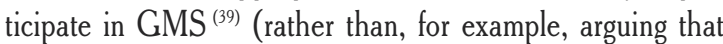
Yunnan "naturally" belonged to the region). This unusual membership structure raises the question of how China's involvement in GMS programmes has been managed. From the outset, China's chief representatives at GMS meetings have been from the central government, ${ }^{(40)}$ with the delegations including a mixture of central and Yunnan provincial government representatives, and a provincial government representative as deputy delegation leader.

\section{Perspectives from the centre}

The most recent detailed publicly-available document from China's central government, hereafter the "Country Report," (41) was prepared for the Vientiane GMS Leaders
Summit in March 2008 by the National Development and Reform Commission, the Ministry of Foreign Affairs, and the Ministry of Finance. The text refers consistently to "China" (not Yunnan and Guangxi) as the participant in GMS, and shows signs of substantial central coordination of Chinese activity. It refers to Yunnan and Guangxi as "the regions of China to participate directly in GMS cooperation," (42) adding that both provinces need to increase their openness in order to develop. Its emphasis, therefore, is more on the GMS of six members than the GMS as a geographical area. This in effect increases the weight given to the role of the central authorities in China's GMS-related activity, possibly as the result of central government efforts to control the agenda as part of an ongoing dialectic between central and local authorities.

The Country Report offers analysis of China's bilateral trade with each of the five other members of GMS, showing that China has substantial surpluses with all except Thailand. While trade and investment are on the GMS agenda, commercial activity is far from constrained within the GMS structure, and I suggest that the Chinese emphasis is an example of China using the GMS to promote a wider agenda with the Mekong members. The Country Report also outlines China's activity against a series of themes that broadly correlate to the main sectors of GMS Programmes, ${ }^{(4)}$ including the challenges of avian flu, drugs, human trafficking, and maintaining biodiversity. The Country Report has little on water and river management:

\section{Dosch, op. cit., p. 135.}

38. Further work could supplement this with a wider range of bottom-up views from within China. As noted above, the extensive broader literature on China and ASEAN also gives a wider context.

39. Yang, op. cit., p. xii.

40. China's representation at the early meetings was at a much lower level than the other five countries. While the five sent Ministers or in some cases Deputy Prime Ministers, China's delegation was headed by the Acting Director of the International Department of the People's Bank of China in both 1993 and 1994 (ADB, Economic Cooperation In The Greater Mekong Subregion: Proceedings of The Second Conference On Subregional Economic Cooperation, 30-31 August 1993, Manila, Asian Development Bank, 1993; and ADB, Subregional Economic Cooperation: Proceedings Of The Fourth Conference, Chiang Mai, Thailand, 15-16 September 1994, Manila, Asian Development Bank, 1994). The seniority of the Chinese representative at the November 1995 meeting was greater: the deputy minister-level Vice Chairman of the State Planning Commission (ADB Economic Cooperation In The GMS: Facing The Challenges, Manila, Asian Development Bank, 1996).

41. Country Report on China's Participation in Greater Mekong Subregion Cooperation 2008, downloaded from http://en.ndrc.gov.cn/ July 2008 (henceforth "Country Report").

42. Ibid., p. 21.

43. The Chinese report uses "communication" for transport, separates out health cooperation as a separate area, and combines trade and investment into one section, but otherwise is structured in the same way as the Plan of Action agreed by GMS national leaders in Vientiane (ADB, Vientiane Plan of Action for GMS Development 2008-2012, 2008, downloaded from www.adb.org July 2008). 
there are brief references to hydropower under energy, as well as a reference to dredging work between Jinghong (southern Yunnan) and the Burmese border, which aims to make that part of the river navigable by $300 \mathrm{t}$ vessels, but which has also led to concerns from downstream countries about its impact on river flow.

These central views are reflected in some of the papers delivered at a conference in Yunnan's provincial capital Kunming in 2005 and collated in a volume published by the Chinese Academy of Social Sciences (CASS) in 2007. ${ }^{(4)}$ Taken together, these essays present a broadly positive assessment of developments in the region. Although the volume is entitled "A study on economic cooperation in the Greater Mekong Subregion," a number of the contributors, especially those from Beijing, focus on China and ASEAN issues with scant reference to the Mekong or GMS. This suggests that over recent years at least, Mekong regional cooperation has been increasingly seen as part of a bigger picture of China's developing relations in the wider southeast Asian region - one contributor conceptualises GMS as a land route to southeast Asia for China. ${ }^{(45)}$

The volume is introduced by Zhang Yunling, head of the Asia-Pacific research centre at CASS in Beijing. Zhang argues that economic cooperation is about more than developing a free-trade area, and hence there is value in GMS cooperation beyond the aims of a free trade agenda. Of the other CASS contributors, Lu Jianren outlines what he sees as the "backwardness" of the GMS region and China's positive contribution to its development, while Zhou Xiaobing argues that the central government has become more focused over time on the GMS, having initially seen it as more an issue for local government participation. Cai Yu notes that GMS is driven by government activity and not the private sector, and reiterates the point that it is functionally based rather than a nascent free-trade area, giving it objectives and structure different from those of ASEAN.

\section{Provincial perspectives - Yunnan...}

Contributions to the same volume by scholars from Yunnan (both the provincial Academy of Social Sciences and Yunnan University) paint more local and detailed pictures. $\mathrm{He}$ Shengda stresses Yunnan's role as the "main Chinese province" in GMS, and calls on the central government to make more of this. For Zhang Lin, GMS cooperation should go beyond the economic sphere to increase the accumulation of social capital. Other scholars from Yunnan University focus on specific areas, for example arguing that the competence structure of the GMS is weak and the region's ability to attract foreign direct investment is therefore limited, highlighting the differences within the region in levels of logistics and manufacturing development, the different demographics between countries within GMS, and the need for international cooperation to control the trade in and use of illegal drugs.

Many of these themes are reflected in Yunnan government publications. Yunnan Provincial Economic Statistical Yearbooks contain substantial sections on regional economic cooperation that are dominated by developments within "the GMS," while much less coverage is given to the issue of economic cooperation with other provinces in China (the third area covered in recent years is Yunnan's growing links with India, Bangladesh, and Burma under a separate institutional structure). The GMS material began to appear in the Yearbook in 2002, ten years after the GMS was established, and the year of the first GMS national leaders' summit, which followed the injection of new life into GMS around 2001. This 2002 entry offers a brief introduction to the background of the GMS, stressing economic cooperation between the countries involved rather than any hints of the creation of a regional bloc or identity. It also mentions the MRC and China's "participation" in water resource sharing, giving a more positive picture than that painted by those who criticise China for not joining or cooperating with the MRC. ${ }^{(46)}$

Subsequent Yunnan Yearbook entries say less about either the GMS as an institutional framework or the ADB, with references limited to describing attendance by Yunnan's leaders at GMS meetings and summits. Rather, the content provides paragraph summaries of specific projects involving Yunnan and other countries - or sometimes provinces of these countries - within the GMS region. These range across the sectors covered by GMS, including hydropower projects, the opening of road, rail, or air links, the facilitation

44. CASS: Cai Yu, Lu Jianren, and Yang Xianming (eds), Da Meigong he ci quyu jingji hezuo yanjiu (A study on economic cooperation in Greater Mekong Subregion), Beijing, Shehui kexue wenxian chuban she, 2007.

45. A separate record of a UN Development Programme-sponsored conference in April 2002 in Kunming on GMS economic cooperation puts the topic in the context of the creation of a China-ASEAN single market of 450 million people (downloaded from www.yn.gov.cn, July 2008).

46. Vietnamese views in particular express dissatisfaction with China's role and actions. See for example the series of contributions from Vietnamese scholars in Dosch et al. (eds), Economic and Non-traditional Security Cooperation in the Greater Mekong Subregion, Singapore: Konrad Adenauer Foundation, 2005. However Kayo Onishi ("Hydropolitics of China and Downstream Countries in the Mekong River Basin," downloaded from www.mekongnet.org/images/b/b6/0nishi.pdf), sees China as "gradually compromis[ing] with downstream countries." 
of border crossing through issuing visas at ports, and visits to and from Yunnan by official delegations. There are also descriptions of commercial projects, such as an agreement with Laos granting exploration rights to the Yunnan Copper Company, ${ }^{(47)}$ which are arguably more dependent on the relevant bilateral relationship than on the GMS. The overall impression created is of Yunnan proactively building links and developing cooperation, rather than of a six-sided cooperative structure delivering regional integration, or of a nascent borderless region, an impression that takes us outside the GMS institution to wider regional activity. Separately, efforts in Yunnan to build a regional concept can be seen in a popular history and tourism book that the author describes as part of the Yunnan government's external publicity work. ${ }^{(48)}$ It is based around the Mekong River as the "cradle of Indochina's Peninsular Culture," and against a background of the Mekong becoming "more submerged in an ever-increasing tide of globalization and regional integration." (49)

\section{... and Guangxi}

Although Guangxi does not share the Mekong basin, the geographical involvement of China in GMS was extended to include Guangxi in March 2005. In a page on its website entitled "Broadening the Benefits," the ADB justifies Guangxi's inclusion as "one of two provinces in the PRC that share borders with other GMS countries" (i.e., Vietnam). It sees the province's participation as "a natural northward extension of the GMS' [sic] geography - a clear outcome of strengthening economic relations between the PRC and other GMS countries." ${ }^{\left({ }^{00}\right)}$ This shows that the GMS regional conception has become further divorced from the Mekong River itself.

Given the potential for economic competition between China's provinces, ${ }^{(51)}$ it is worth looking at Yunnan's reactions to Guangxi's subsequent membership of GMS. Yunnan's 2006 Economic Statistics Yearbook refers to Guangxi's participation in GMS cooperation being agreed in March 2005, following a "suggestion" by Premier Wen Jiabao in November 2004. This is described as a symbol of China's commitment to cooperation with the five countries, as well as an opportunity for Guangxi. However $\mathrm{He}$ Shengda from the Yunnan provincial Academy of Social Sciences stresses that Yunnan is the main Chinese representative in GMS. ${ }^{(52)}$ Material from the Yunnan Government website, prepared around the time of the GMS summit in Kunming in 2005 and when Guangxi's participation was already known, says that China's participation means participation by Yunnan. ${ }^{(33)}$ At a June 2008 meeting of the GMS Economic Corridor Forum in Kunming, provincial Governor Qin Guangrong said that Yunnan was China's "main province" for participation in GMS and was at the frontline of cooperation. ${ }^{(54)}$ I suggest this indicates that Guangxi remains marginal to Yunnan's construction of a Mekong region.

Guangxi's own provincial government yearbooks and website do not give much prominence to GMS cooperation, with only passing references in talking about tourism development. ${ }^{(5)}$ Neither is Guangxi's contribution explored by the literature reviewed for this paper, which focuses predominantly on Yunnan. Although understandable, given Guangxi's late participation, this is sometimes problematic, for example in $\mathrm{McC}$ askill et al, ${ }^{(56)}$ which contains a map of the GMS including Guangxi, but the text of which defines and discusses a GMS that includes only Yunnan.

\section{Differentiating central and provincial constructions}

Given the limitation of China's geographical participation in the GMS to Yunnan and Guangxi, the always significant central-local dynamic takes on an added layer of complexity. Although views can be sought at a range of levels both officially and unofficially, I will limit comments in this paper to comparing central and provincial government perspectives. At the provincial level, especially in Yunnan, the stress has consistently been placed on the "GMS area," the geographical territory covered by cooperation programmes under the GMS, and which has privileged Yunnan as a key player. Even with Guangxi's subsequent

47. Yunnan Provincial Government Statistical Yearbook, 2006, pp. 208-217

48. Liu Zhi, Zong lan liang an jin xi (Past and present of Mekong Basin), Kunming, Yunnan minzu chuban she, 2004.

49. Quoted from the English language summary. "Indochina Peninsular" is the English version used for the zhongnan bandao (see comments below)

50. www.adb.org, downloaded June 2008

51. See for example Dali Yang, Beyond Beijing, 1997, where he talks inter alia about "competitive liberalization" among local governments (chapter 3).

52. CASS, op. cit.

53. "... China refers to Yunnan Province, China," Da Meigong he ciquyu hezuo beijing (Background on Greater Mekong Subregion Cooperation), dated 23 June 2005, downloaded from www.yn.gov.cn on 3 July 2008. The same emphasis was given by a range of Yunnan officials whom I met on visits to the province.

54. Kunming Daily, 7 June 2008, p. 1.

55. Guangxi Provincial Yearbook 2006, p. 295.

56. McCaskill et al., op. cit. 
admission into the GMS territory, the vision of the region from Yunnan's capital Kunming is one in which Yunnan Province is the paramount Chinese participant. The central government, however, most notably through the Country Paper, emphasises the "GMS members" as the core of the GMS concept, in other words a region made up of China (represented by the central government) and the five other GMS member countries. ${ }^{(57)}$ It is worth noting that the high-profile involvement of Chinese Premier Wen Jiabao in the GMS national leaders' summits (most recently in Vientiane in 2008) stands in marked contrast to the relatively low level of the Chinese delegation at GMS meetings in the early 1990s (footnoted above). Zhou Xiaobing of CASS (noted above) also argues that the central authorities have taken the GMS more seriously over time, perhaps reflecting the increased capacity of the state since the 1990s, or decentralisation trends of the 1990s and their subsequent reversal.

There is also differentiation between the centre and the province in their functional focus. For Yunnan, GMS helps meet the devolved challenges of economic development, whereas for the centre the importance of economic development is somewhat counterbalanced by non-traditional security challenges and the traditional security issues around national borders.

There is a further layer of differentiation both centrally and provincially when referring to the GMS. Chinese writing on the region appears to display a dialectic between GMS as an institutional structure and GMS as a geographical or member-based region, with, for example, the geographical aspect reflected in the Yunnan provincial yearbooks and in the Country Report's treatment of trade, and the institutional aspect reflected in discussion of transport integration. This cannot simply be seen as the subjugation of the institutional structure to a wider agenda of regional cooperation or integration, as it is the institutional development that gives legitimacy to this wider regional agenda.

I further argue that China's role in the GMS seems to indicate that, in spite of the devolution within the PRC to the provincial level of much of the responsibility for economic development, the centre retains a strong say in those elements of economic development that cross borders, and in doing so promotes a dominance of politics over economics even at the expense of the ostensible goal of economic development. On the basis of this study, the development of substantial provincial international policy towards economic development therefore looks to be in its early stages at most.

\section{Dominant Chinese constructions of the region}

That said, there are also broad areas of similarity in central and provincial approaches. In this penultimate section of the paper I look at how general Chinese constructions of the region relate to the four conceptual themes outlined earlier in problematising the Mekong region. In spite of an initial lack of enthusiasm for the GMS programme, ${ }^{(58)}$ the dominant perceptions of the Mekong region that emerge both centrally and provincially from the material reviewed above are a conception of the region as an instrument for economic development and cooperation, with the GMS and its political boundaries (in terms of membership and area) defining the region. There is a substantial overlap here with the ADB agenda, and it is worth noting Chinese comments that present the ADB as the driving force behind the establishment of GMS. The Country Report describes GMS as having been set up "in response to the advocating (sic) by Asian Development Bank," while an earlier background page on the Yunnan government website described the GMS as having been established by the ADB. ${ }^{(59)}$ Privileging of the GMS is also consistent with the argument that China's multilateral engagement is stronger in institutions where its influence is greater. ${ }^{(60)}$ The GMS offers cooperation both on a positive agenda of development that fits variously with central and provincial priorities, and - latterly - in dealing with some non-traditional security threats, such as infectious diseases or drug and human trafficking, that do feature marginally in Chinese approaches.

The theme of river management hardly features in Chinese discourse. At neither the central nor local level does cooperation in managing this water resource appear to be a high priority, although the extent of dam building on the Mekong does indicate an interest in hydropower "development" of the river to meet both wider national and provincial goals. ${ }^{(61)}$ The MRC, which is based on a construction of the region

57. This is a rather more nuanced account than "[i]n this context [GMS], Yunnan functions more as a separate unit than a pod of the central state" or "Yunnan functions as a comparable unit among its neighbouring countries in the GMS"; in Margaret Swain, "Looking South: Local identities and transnational linkages in Yunnan," in John Fitzgerald (ed), Rethinking China's Provinces, London and New York, Routledge, 2002, pp. 197-8. Swain has underplayed the role of the central government.

58. At least at the central government level, see footnote 40 above.

59. Country Report, op. cit., p. 3; and material dated 23 June 2005 from www.yn.gov.cn, downloaded 3 July 2008.

60. See the Introduction by the editors in Guoguang Wu and Helen Lansdowne (eds), China Turns to Multilateralism: Foreign Policy and Regional Security, London and New York, Routledge, 2008, p. 12

61. See Magee, art. cit. 
around the river basin, brings problems to China in the form of demands from downstream neighbours for more information on the upstream river situation, and requests to reduce hydropower development on the Chinese stretch of the river. I suggest that the integration theme characteristic of $\mathrm{ADB}$ work is generally recast in Chinese thinking in terms of cooperation between states. This is consistent with the argument that regional organisations of which China is a member "have largely eschewed any movement toward supranationality." ${ }^{(22)}$ Nonetheless, the shift in Beijing's strategy towards southeast Asia from the 1990s, and in particular participation in GMS, does have an integrationist flavour, reflecting a more flexible approach to cooperation with neighbours, and implicitly to sovereignty, than before the 1990s. It involves willingness to engage in joint planning of regional infrastructure (transport and energy grids), and potentially in other areas of cooperation where rescaling to a regional level is most evident. This is complemented by a stated desire to work with neighbouring countries in tackling challenges such as drugs or infectious diseases.

However, other areas do not reflect this shift. Even when the ADB talks of a borderless region, the specific projects set out under this vision are more about facilitating the crossing of borders than eliminating them. ${ }^{\left({ }^{(3)}\right)}$ Given China's keen desire to retain control of border security, for example, there is little evidence of progress in plans for a GMS visa (which should somehow involve China as a GMS member), and indeed this remains at the aspirational stage in the most recent $\mathrm{ADB}$ documents. ${ }^{\left({ }^{64)}\right.}$ Yang finds that security concerns have acted as a constraint on the more ambitious plans for integration and opening of markets. ${ }^{(65)}$ And the prominent role given to GMS leaders' summits in setting the direction for GMS cooperation reinforces the sense that the nation state remains a key power container in the region. This in turn suggests that Mekong region cooperation falls far short of the post-nation state integrationist thesis set out in some recent works. ${ }^{(66)}$

\section{China and the region - participation or difference?}

Finally, I ask to what extent these constructions take China as separate from or part of the Mekong region (a distinction perhaps made concrete by comparing its role in the GMS and $\mathrm{MRC}$ respectively), not least given the political divide between China and southeast Asia reflected in both institutional structures and in foreign policy from 1949 until the PRC's reform and opening. The Country Report in partic- ular is careful to refer to China and "the other GMS countries" (my emphasis), sending the message that China is not to be seen as outside the (sub)region but participating in it. However, there are other indicators in counterpoint to this. One is the reference on the first page of the Country Report to the region as a "land bridge connecting China with southeast Asia and south Asia," creating the impression of something to which China does not belong, and which must be crossed in order to achieve a wider goal.

This raises the issue of the relationship between Chinese views of the Mekong region and broader views of Southeast Asia and East Asia, including through institutional relationships with ASEAN. All the GMS countries are now members of ASEAN, although it is important to note that this was not the case when GMS cooperation began. ${ }^{(67)}$ Some scholars ${ }^{(68)}$ now put the GMS in the wider context of the China-ASEAN relationship, privileging the latter over the earlier institutional work through GMS, even though (as noted above) the nature of GMS cooperation is different from that in ASEAN. Even at the Yunnan provincial level, where a continued focus on GMS might be considered in the province's economic interest, an increasing amount of work is being done on the impact on the province of the China-ASEAN free trade agreement. The question remains as to what extent Chinese actors are beginning to see the former simply as part of the latter.

A second indicator of differentiation in respect of China's relationship to the Mekong region is the naming underlying Chinese discourse on the river itself. Chinese sources introduce the river as the "Lan Cang" river within China's borders, and the Mekong once it leaves China. This does not account for the multiple and varied namings of the river along its full length, ${ }^{(69)}$ nor indeed near its source in China,

62. T G Moore, "Racing to Integrate, Or Cooperating to Compete," in Wu and Lansdowne (eds), op. cit., p. 43.

63. For example the section entitled "Making It Happen" in ADB, The GMS, Beyond Borders, op. cit., pp. $31 \mathrm{ff}$.

64. ADB, Vientiane Plan of Action, 2008, p. 61.

65. Yang, op. cit.

66. For example in Kenichi Ohmae, The End of the Nation State, New York, Free Press, 1995.

67. Vietnam, Laos, Myanmar, and Cambodia joined ASEAN between 1995 and 1999

68. For example, He Shengda and Sheng Lijun's essay on Yunnan's GMS strategy in Saw Swee Hock, Sheng Lijun, Chin Kin Wah (eds), ASEAN-China Relations: Realities and Prospects, Singapore, Institute of Southeast Asia Studies, 2005.

69. Sahai (op. cit., p. 17) translates the names in various downstream countries as "Nine Dragons" (Vietnam), "Great Water" (Cambodia), "Mother of Waters" (Thailand and Laos). Sahai, Osbourne, and Hori (op. cit.) also note the use of different names at the local level. With the single name Mekong often used at the regional level, the identity of the river is thus different when scaled at the local, national, or regional levels, with political boundaries affecting how the river is perceived. 
where " $\mathrm{Za} \mathrm{Qu}$ " is used, ${ }^{(70)}$ and indicates the dominance of the Yunnan section in domestic discourse on the river. But this naming also reflects a perception of the non-Chinese part of the GMS region - or in other contexts, southeast Asia - as a kind of isomorphic or unitary "other" to China. This bifurcation is also revealed in the language used to refer to the geographical areas. Chinese sources, when not talking about the "GMS" (for example da meigonghe ciquyu hezuo), often use either yinzhi bandao or zhongnan bandao. The first of these is a transliteration of the term "Indochina peninsula," which dates from the colonial period and was also used by the Japanese during the Second World War, but its usage does not make clear whether it refers to the whole peninsula, including Thailand, or to the part of it that was previously constituted as French Indo-China. The latter term, which would most obviously translate literally as "south (of) China peninsula," is somewhat ambiguous, but clearly Sino-centric, suggesting the peninsula as an extension from (or to) China's south. Others tend to use the term "southeast Asia" (dongnanya), a mid-twentieth century term that is geopolitically more neutral. ${ }^{(71)}$ This is understood to cover at least the area of the ten ASEAN countries, a much larger land mass than the peninsula, leading to the use of "mainland southeast Asia."

Naming both the river and the land mass through which it runs is therefore highly problematic, with the choice of names reflecting the identity of the agent of regional construction for projects of integration, resource management, or economic cooperation. The names also reflect who is marginalised by such projects, such as the local inhabitants who have lost their indigenously-named river to a greater regional identity.

This ambiguity is reflected in the wider scholarship. The ADB's institutional structure, which led to the term "subregion" being used, ${ }^{(72)}$ is indicative of a typology not unique to the ADB. Most of the scholarship, if it has a geographical focus, tends to be from a dominant perspective of either southeast Asia or China. Many of the studies on the Mekong region have been produced by specialists on southeast Asia, and perhaps as a result the coverage of China within this literature is somewhat limited. The Chinese studies literature that has crept as far south as the areas of Yunnan that could be construed as part of a Mekong region has tended to focus either on specific cross-border issues such as trade, or on internal Chinese political or economic developments in that area. Attempts to bridge this divide often structure the analysis by placing China and southeast Asia (or a subset thereof) as two parties in the formulation of the region. We saw above that in spite of some Chinese government efforts to emphasise participation in the region, other Chinese discourse served to reflect the ingrained sense of China being contrasted to the areas over its border into southeast Asia. This can either privilege China's position or undermine it by setting it up as the focus of "problems," as in the Vietnamese discourse footnoted above, which picks out China as the upstream villain. It also constructs a semblance of unity within the southeast Asian part of "the region," giving insufficient space to differences between actors within that geographical area, ${ }^{(73)}$ a separate but related issue that warrants more comment in the context of relations between China and its southeast Asian neighbours.

\section{Conclusion}

By tracing various Chinese constructions of the Mekong region, this paper has explored one aspect of China's increasing engagement across its continental borders with southeast Asia. Against a background of growth in regional mechanisms for cooperation and integration, it shows the dominance of economic motivations in China's engagement with the region, expressed through its privileging of the GMS mechanism, but with subtly different central and provincial approaches. This, in turn, shows the tension between China's participation in and differentiation from this region stretching over China's southwest continental borders. •

70. Hori, op. cit., p. 3.

71. This term, too, has its political overtones. According to Bakker (art. cit., p. 219) the term "entered into conventional usage only in the mid-20th century, following its adoption as the title of the Allied military authority responsible for dispossessing Japan of territorial gains made during the Pacific War."

72. Footnote 14 above.

73. A recent (2008) example of differences within the region is the dispute between Thailand and Cambodia over the Hindu temple Preah Vihear on the border between the two countries (see e.g. "Disputed temple becomes political football threatening a government," South China Morning Post, 10 July 2008 and subsequent reports). 